\title{
Innocent or guilty? Redox activity in and magnetic and optical behaviour of dinuclear molydenum complexes
}

\author{
JON A MCCLEVERTY* and MICHAEL D WARD \\ School of Chemistry, University of Bristol, Cantocks Close, Bristol BS8 1TS, \\ UK \\ e-mail: Jon.McCleverty@bristol.ac.uk
}

\begin{abstract}
The phenomenon of 'non-innocence', first articulated by Jørgensen in 1966 , is briefly reviewed. Spectroelectrochemical studies of a range of dinuclear complexes of the type $\left[\{\mathrm{Mo}(\mathrm{NO}) \mathrm{Tp} * \mathrm{Cl}\}_{2}\right.$ (bridge) $($ bridge $=$ dipyridyls) and $\left[\{\mathrm{Mo}(\mathrm{O}) \mathrm{Tp} * \mathrm{Cl}\}_{2}\right.$ (bridge) $]$ (bridge $=$ diphenolates) which are redox active, show that oxidised or reduced forms of these species exhibit 'non-innocence'. The spectral behaviour is associated with metal-to-ligand or ligand-to-metal charge transfer phenomena, probably the first time that monodentate bridging ligands have been implicated in 'non-innocent' behaviour. These bridging ligands also determine the nature and extent of magnetic interaction between the unpaired spins in $\left[\{\mathrm{Mo}(\mathrm{NO}) \mathrm{Tp} * \mathrm{Cl}\}_{2}(\right.$ bridge $\left.)\right]$ and $\left[\{\mathrm{Mo}(\mathrm{O}) \mathrm{Tp} * \mathrm{Cl}\}_{2}\right.$ (bridge) $]$, the dominant mechanism of spin-exchange relying on the extent of $\partial$-delocalisation within the bridging ligands. The unusual optical behaviour of these dinuclear complexes when oxidised (oxomolybdenum diphenolates) or reduced (nitrosyl molybdenum dipyridyls) has led to the exploration of electrochromism as a means to develop variable optical attenuators operating in the near-infrared region.
\end{abstract}

Keywords. Molydenum; nitrosyl; non-innocence; spectroelectrochemistry; magnetic exchange; electrochromism.

\section{Introduction}

\section{$1.1 \quad$ Non-innocence}

The concept of ligand 'innocence' in chemistry was introduced by C K Jørgensen in the mid 1960s at a time when dithiolene chemistry was being developed by the groups of Davison, Holm, Gray and Schrauzer and their coworkers ${ }^{1}$. The issue was the definition of oxidation states when there were situations of apparent ambiguity, some examples of which are given below. Jørgensen's definition to circumvent ambiguous situations was to state that 'ligands are innocent when they allow oxidation states of the central metal atom to be defined' 2 .

No oxidation state ambiguity arises in compounds such as $\left[\mathrm{Nb}(\mathrm{CO})_{6}\right]^{-3},\left[\mathrm{Cr}(\mathrm{CN})_{6}\right]^{6-}$ and $\left[\mathrm{Ni}\left(\mathrm{PPh}_{3}\right)_{3} \mathrm{Cl}\right]$, which contain $\mathrm{Nb}(-\mathrm{III}), \mathrm{Cr}(\mathrm{O})$ and $\mathrm{Ni}(\mathrm{I})$ respectively although there may be some discomfort about the notion of negative oxidation states!

However, the situation with metal nitrosyls is different and relates to the possibility that the $\mathrm{NO}$ ligand is coordinated as $\mathrm{NO}^{+}, \mathrm{NO}^{-}$(neutral) or $\mathrm{NO}^{-}$. The formal oxidation state of the metal in, for example, $\left[\mathrm{Fe}(\mathrm{NO})\left(\mathrm{H}_{2} \mathrm{O}\right)_{5}\right]^{2+}$ may be defined as III $\left(\mathrm{NO}^{-}\right)$,

*For correspondence 
II $\left(\mathrm{NO}^{*}\right)$ or I $\left(\mathrm{NO}^{+}\right)$. In $\left[\mathrm{IrCl}(\mathrm{CO})(\mathrm{NO})\left(\mathrm{PPh}_{3}\right)_{2}\right]^{+}$the $\mathrm{NO}$ charge formalism leads to $\mathrm{Ir}^{\mathrm{III}}$ $\left(\mathrm{NO}^{-}\right)$, Ir ${ }^{\mathrm{II}}\left(\mathrm{NO}^{*}\right)$ or $\operatorname{Ir}^{\mathrm{I}}\left(\mathrm{NO}^{+}\right)$. Actually, the situation in this iridium complex seems reasonably clear since the $\mathrm{Ir}-\mathrm{N}-\mathrm{O}$ bond angle is $\sim 120^{\circ}$, indicating that the nitric oxide is reduced and bound formally as $\mathrm{NO}^{-3}$. However, $\mathrm{NO}$ as a ligand always presents difficulties for the determination of metal oxidation states, and so is regarded as a 'noninnocent' ligand. This is particularly well illustrated by the 3-membered electron transfer chain trans- $\left[\mathrm{Fe}(\mathrm{NO})(\right.$ cyclam $) \mathrm{Cl}^{z+}$, where $z=0,+1$ and +2 (cyclam $=1,4,8,11$-tetraazocyclotetradecane $)^{4}$. Whatever rationalisations one might dream up for the formal oxidation state of the iron and the NO group, a beautiful combination of vibrational, electronic and EPR spectroscopic, spectroelectrochemical, Mössbauer spectral and magnetic susceptibility studies show that the situation is truly 'non-innocent'. The monocation trans-[Fe(NO)(cyclam)Cl] $]^{+}$is proposed to contain an intermediate spin Fe(III) centre $(S=3 / 2)$ antiferromagnetically coupled to $\mathrm{NO}^{-}(S=1)$, while the oneelectron oxidised species $(z=+2)$ appears to contain $\mathrm{Fe}(\mathrm{IV})(S=\mathrm{IV})$, also coupled antiferromagnetically to $\mathrm{NO}^{-}(S=1)$. One-electron reduction of the monocationic $(z=+1)$ species leads to the neutral complex trans-[Fe(NO)(cyclam)Cl] in an apparently nitrosyl-ligand-centred process, affording a species containing low spin $\mathrm{Fe}(\mathrm{III})(S=1 / 2)$ antiferromagnetically coupled to what is formally described as $\mathrm{NO}^{2-}(S=1 / 2)$. These proposals are remarkable and whether credible or not, underline the 'non-innocence' of complexes containing NO.

As mentioned above, it was dithiolene chemistry that presented the earliest challenge to oxidation state formalities. Perhaps the most dramatic situation was illustrated by the series of complexes represented as $\left[\mathrm{V}\{\text { dithiolato }\}_{3}\right]^{z}(z=0 \text { or }-1)^{5}$. If it is assumed that the chelating sulfur ligand is formally dianionic, then when $z=0$ the oxidation state of the central metal must be defined formally as VI: plainly nonsense! When $z=-1$, an assignment of metal oxidation state as +5 is apparently reasonable except for the consideration that such a high oxidation state can be supported by highly polarisable sulphur ligands! The complexes with $z=0$ or -1 have slightly distorted trigonal prismatic structures and the inter- and intra-ligand $S \cdots S$ distances are close to $3 \cdot 1 \AA$, a situation implying that the sulfur ligand itself may be partially oxidised, leading to weak $\mathrm{S}-\mathrm{S}$ interactions. A detailed examination of the spectroscopic properties of these compounds coupled to molecular orbital calculations has been, to say the least, somewhat confusing, but when stripped to the basic arguments, appears to show that the formal oxidation state of the metal might be closer to +4 , and that the highest filled or partly filled MOs of this species are predominantly of sulfur ligand $\partial$ symmetry. It seems very probable that these highly oxidised species owe their unusual structural properties to a combination of moderately high metal oxidation states and partially oxidised sulphur ligands. It can also be seen that the HOMOs in the species [V $\left.\{\text { dithiolato }\}_{3}\right]^{z}$ switch around depending on the sulphur ligand substituents and on the overall charge on the complexes. This is a clear case of true 'non-innocence'. It was actually suggested as early as 1966 that the behaviour of many of these species might be accounted for by antiferromagnetic coupling between pairs of dithiosemiquinones (radical anion ligands) held together by metals ${ }^{6 a}$, but the idea was not pursued with much enthusiasm at that time. These dithiolene complexes are all members of electron transfer chains, the more reduced members of which do appear to contain 1,2-dithiolato ligands bound to metals in 'normal' and credible oxidation states. As these complexes are progressively oxidised, electrons are increasingly removed from ligand $\partial$-orbitals rather than the metal, this leading, inter alia, to co-operative interactions between the $\mathrm{S}$ atoms and the generation of trigonal prismatic 
structures. But the situation can be complicated by the reorganisation of the ligand and metal frontier redox orbitals in a way that is difficult to predict - this representing 'noninnocent' behaviour not just of the ligands but of the ligands and metal in combination. The most recent manifestation of this behaviour in dithiolene systems occurs in $\left[\mathrm{M}(\mathrm{CO})_{2}\left\{\mathrm{~S}_{2} \mathrm{C}_{2} \mathrm{Me}_{2}\right\}_{2}\right]^{0,-1,-2},(\mathrm{M}=\mathrm{Mo}$ or $\mathrm{W})$, a three-membered electron transfer chain, where Holm has demonstrated conclusively from extensive crystallographic, spectroscopic and DFT studies that the electron transfer reactions are extensively sulphur-ligand based $^{6 \mathrm{~b}}$.

That ligands can participate in redox reactions is not especially surprising. A classic example of this behaviour, in which the ligand is, for the most part, 'guiltless', is in the series of tris(bipyridyl) complexes, exemplified by $\left[\mathrm{Cr}(\text { bipy })_{3}\right]^{n+}$, where $n=3,2,1,0,-1$, -2 and $-3^{7}$. From extensive structural and spectroscopic work, it is clear that the metal in the $3+$ and $2+$ salts contains $\mathrm{Cr}^{\mathrm{III}}$ and $\mathrm{Cr}^{\mathrm{II}}$, respectively. However, the $1+$ and 0 species have electronic spectra which reveal the presence of the well-characterised [bipy] ${ }^{-}$anion, and it seems likely that more highly reduced species result from an increasing population of bipyridyl acceptor orbitals.

One of the most complicated but interesting situations occurs with complexes of 1,2dihydroxybenzene (catechol) and related arenediols. Pierpont showed many years ago that metal complexes containing the catecholato ligand had characteristics not unlike related dithiolene species. Indeed, the term dioxolene was coined to take account of this similarity in behaviour ${ }^{1}$. The chromium complexes $\left[\mathrm{Cr}\left(\mathrm{O}_{2} \mathrm{C}_{6} \mathrm{H}_{2} \mathrm{Bu}_{2}{ }^{t}\right)_{3}\right]^{3-}$ and $\left[\mathrm{Cr}\left(\mathrm{O}_{2} \mathrm{C}_{6} \mathrm{H}_{2} \mathrm{Bu}_{2}^{t}\right)_{3}\right]^{0}$ appeared to be members of an electron transfer chain linking containing two other species having $2-$ and 1 - charges, respectively ${ }^{8}$. These two extreme species, however, could be rationalised by describing the more reduced species as a complex of $\mathrm{Cr}^{\mathrm{III}}$ containing a benzene-1,2-diolate(2-), whereas the more oxidised species could be a complex of $\mathrm{Cr}^{0}$ coordinated by an ortho-benzoquinone. While the first description seems entirely reasonable and is actually consistent with the spectroscopic properties of the complex, the second picture is manifestly unsatisfactory, not the least because quinones are notoriously poor ligands. However, Pierpont, Hendrickson and others pointed out that while benzene-1,2-diolates are easily oxidised to quinones, that oxidation can pass through a semiquinone state which has significant stability, and some complexes apparently containing catecholato ligands probably contain coordinated semiquinones ${ }^{9}$.

More recent studies of catecholato complexes have shown the extent to which 'noninnocence' is a real factor in the redox behaviour of apparently quite simple complexes. One-electron reduction of $\left[\mathrm{Ni}_{2}\left(\mathrm{O}_{2} \mathrm{C}_{6} \mathrm{H}_{4}\right)_{2}\right]$, which has been shown to contain $\mathrm{Ni}^{\mathrm{II}}$ bound by two semiquinone $\left\{\left(\mathrm{O}_{2} \mathrm{C}_{6} \mathrm{H}_{4}\right)^{\bullet-}\right\}$ ligand, leads to the formation of $\left[\mathrm{Ni}\left(\mathrm{O}_{2} \mathrm{C}_{6} \mathrm{H}_{4}\right)_{2}\right]^{-}$, in which the two formerly semiquinonoidal ligands are reduced to $\left(\mathrm{O}_{2} \mathrm{C}_{6} \mathrm{H}_{4}\right)^{2-}$ (catecholate), while the metal is formally oxidised to $\mathrm{Ni}^{\mathrm{III} 10}$. Similarly, one-electron reduction of $\left[\mathrm{V}\left(\mathrm{O}_{2} \mathrm{C}_{6} \mathrm{H}_{4}\right)_{3}\right]$, which contains $\mathrm{V}^{\mathrm{III}}$ bound by three semiquinonoidal ligands, affords $\left[\mathrm{V}\left(\mathrm{O}_{2} \mathrm{C}_{6} \mathrm{H}_{4}\right)_{3}\right]^{-}$which contains $\mathrm{V}^{\mathrm{V}}$ coordinated by three catecholato ligands ${ }^{11}$. These reductions can be regarded as addition of one electron to a semiquinone-like ligand followed by substantial reorganisation of the metal $d$ and ligand $\partial$-orbitals, leading to electron redistribution: in the nickel case to formation, notionally, of $\left[\mathrm{Ni}^{\mathrm{II}}(\mathrm{sq})(\mathrm{cat})\right]^{-}$ followed by reorganisation to $\left[\mathrm{Ni}^{\mathrm{III}}(\mathrm{cat})_{2}\right]^{-}$; and in the vanadium case of conversion initially (and notionally) to $\left[\mathrm{V}^{\mathrm{III}}(\mathrm{sq})_{2} \text { (cat) }\right]^{-}$and then reorganisation to $\left[\mathrm{V}^{\mathrm{V}}(\mathrm{cat})_{3}\right]^{-}$reduction of one ligand followed by transfer of two electrons from the metal to the two remaining semiquinone ligands. 


\subsection{General behaviour of dinuclear molybdenum complexes}

In initially unrelated work, we have been investigating dinuclear nitrosyl and oxo complexes of molybdenum for several years ${ }^{12}$. These complexes have been of interest because of their remarkable magnetic and optical properties, which has led us recently to report systems containing the $\{\mathrm{Mo}(\mathrm{NO})\}^{n+}$ and $\{\mathrm{Mo}(\mathrm{O})\}^{n+}$ moieties which exhibit redoxswitchable magnetic ${ }^{13}$, non-linear optic ${ }^{14}$ or NIR electrochromic behaviour ${ }^{15}$. The compounds of interest to this discussion contain $4,4^{\prime}$-dipyridyls and $4,4^{\prime}$-diphenolato ligands: the former bridging molybdenum nitrosyl termini, e.g. $\left[\left\{\mathrm{Mo}(\mathrm{NO}) \mathrm{Tp}^{*} \mathrm{Cl}\right\}_{2}\right.$ (dipy)] $\quad\left(\mathrm{Tp}^{*}=\right.$ tris(3,5-dimethylpyrazolylborate, dipy = generic class of dipyridyl ligands) and the latter connecting oxomolybdenum groups, e.g. $\left[\{\mathrm{Mo}(\mathrm{O}) \mathrm{Tp} * \mathrm{Cl}\}_{2}\right.$ $\left.\left\{\mathrm{OC}_{6} \mathrm{H}_{4} \mathrm{EC}_{6} \mathrm{H}_{4} \mathrm{O}\right)\right]$ (figure 1). Both of these systems are redox-active, forming fourmembered electron transfer chains:

$$
\begin{aligned}
& {\left[\left\{\mathrm{Mo}(\mathrm{NO}) \mathrm{Tp}^{*} \mathrm{Cl}\right\}_{2}(\mathrm{dipy})\right]^{2-} \square\left[\left\{\mathrm{Mo}(\mathrm{NO}) \mathrm{Tp}^{*} \mathrm{Cl}\right\}_{2}(\operatorname{dipy})\right]^{-} \square} \\
& \left.\left[\left\{\mathrm{Mo}(\mathrm{NO}) \mathrm{Tp} \mathrm{p}^{*} \mathrm{Cl}\right\}_{2} \text { dipy }\right)\right] \square\left[\left\{\mathrm{Mo}(\mathrm{NO}) \mathrm{Tp}^{*} \mathrm{Cl}\right\}_{2}(\operatorname{dipy})\right]^{2+}
\end{aligned}
$$

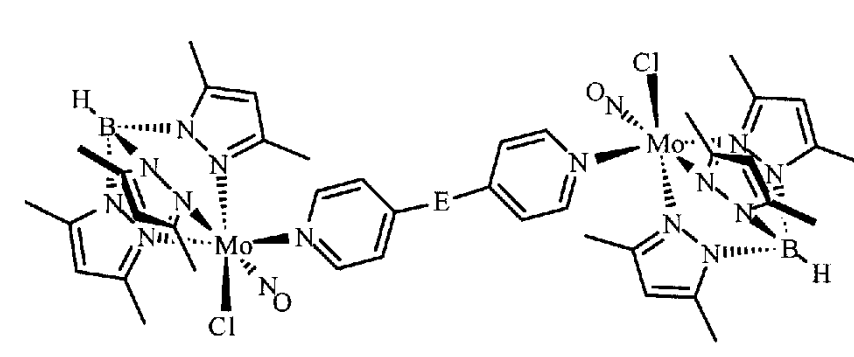
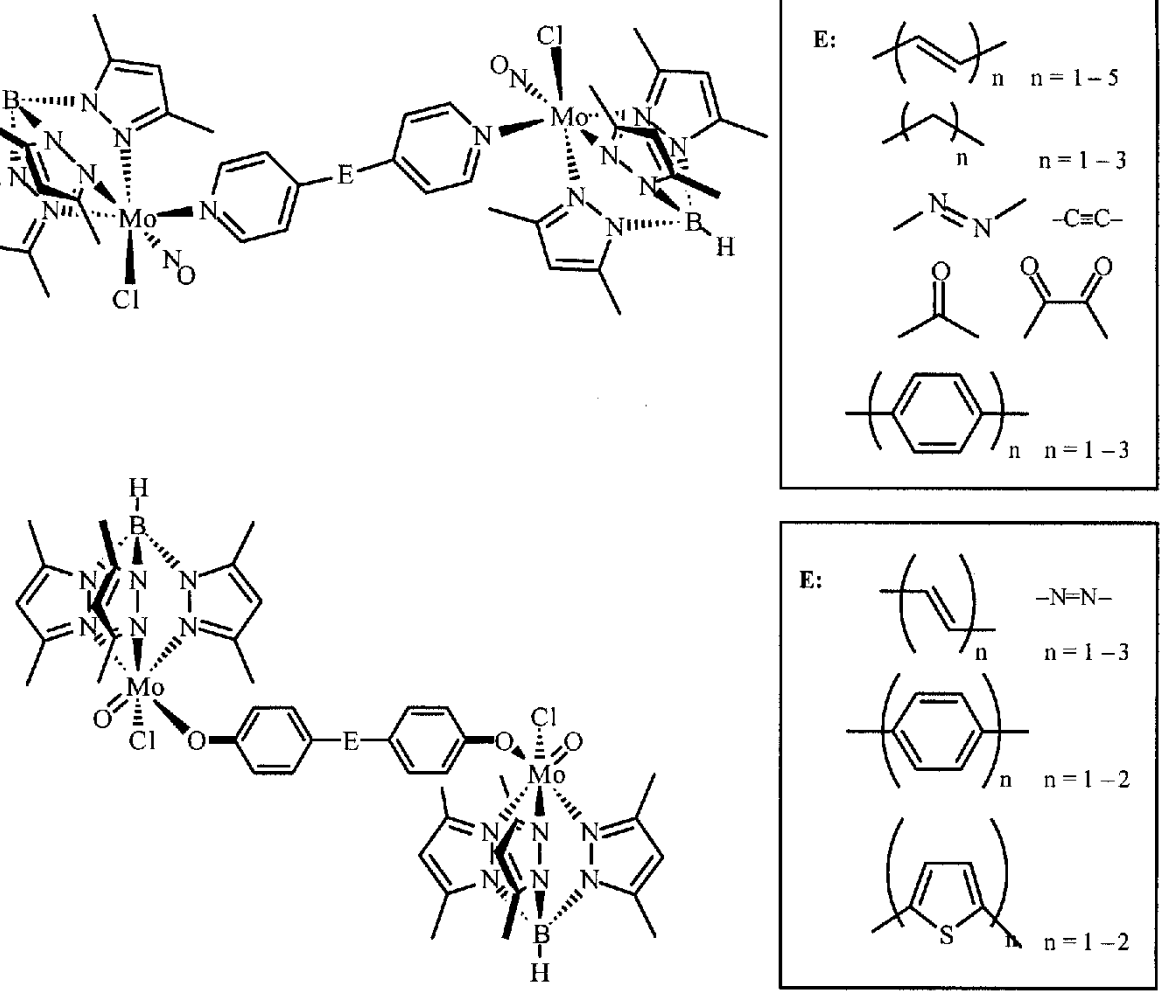

Figure 1. Dinuclear nitrosyl and oxo molybdenum complexes. 


$$
\begin{aligned}
{\left[\{\mathrm{Mo}(\mathrm{O}) \mathrm{Tp} * \mathrm{Cl}\}_{2}\left\{\mathrm{OC}_{6} \mathrm{H}_{4} \mathrm{EC}_{6} \mathrm{H}_{4} \mathrm{O}\right)\right]^{2-} \square } \\
{\left[\left\{\mathrm{Mo}(\mathrm{O}) \mathrm{Tp}^{2} \mathrm{Cl}\right\}_{2}\left\{\mathrm{OC}_{6} \mathrm{H}_{4} \mathrm{EC}_{6} \mathrm{H}_{4} \mathrm{O}\right)\right] \square } \\
{\left[\{\mathrm{Mo}(\mathrm{O}) \mathrm{Tp} \mathrm{TCl}\}_{2}\left\{\mathrm{OC}_{6} \mathrm{H}_{4} \mathrm{EC}_{6} \mathrm{H}_{4} \mathrm{O}\right)\right]^{+} \square } \\
{\left[\left\{\mathrm{Mo}(\mathrm{O}) \mathrm{Tp} \mathrm{T}^{*}\right\}_{2}\left\{\mathrm{OC}_{6} \mathrm{H}_{4} \mathrm{EC}_{6} \mathrm{H}_{4} \mathrm{O}\right)\right]^{2+} . }
\end{aligned}
$$

To interpret this electrochemical behaviour, it is first necessary to understand the simple electronic structures of the isolated $\{\mathrm{Mo}(\mathrm{NO})\}^{2+}$ and $\{\mathrm{Mo}(\mathrm{O})\}^{3+}$ moieties. The fragment $\{\mathrm{Mo}(\mathrm{NO}) \mathrm{Tp} * \mathrm{Cl}\}$ formally contains the metal in oxidation state $+1\left(d^{5}\right.$; assuming that the nitrosyl group is formally bound as $\mathrm{NO}^{+}$: remember, this is only a formalism), although an alternative description developed by Enemark and Feltham ${ }^{16}$, which avoids the need to define an oxidation state, would represent the metal nitrosyl core $\{\mathrm{Mo}(\mathrm{NO})\}^{2+}$ as $\{\mathrm{Mo}(\mathrm{NO})\}^{5}$. The oxo species $\left\{\mathrm{Mo}(\mathrm{O}) \mathrm{Tp}{ }^{*} \mathrm{Cl}\right\}^{+}$contains $\mathrm{Mo}(\mathrm{V})\left(d^{1}\right)$. Both $\{\mathrm{Mo}(\mathrm{NO})\}^{2+}$ and $\{\mathrm{Mo}(\mathrm{O})\}^{3+}$ fragments are paramagnetic with one unpaired electron. Despite their differences in formal oxidation state, however, the nitrosyl and oxo species have comparable electrochemical and magnetic properties. This can be explained by first taking the Mo-NO/O axis as the $z$-axis, as shown in figure 2. In the nitrosyl situation, the NO ligand is a strong $\partial$-acceptor and so the two empty NO $\gamma^{*}$ orbitals overlap with the $d_{x z}$ and $d_{y z}$ orbitals, thereby lowering them, but leaving the $d_{x y}$ orbital unchanged. The configuration of the $\mathrm{Mo}(\mathrm{I})$ centres is $d_{x z}^{2} d_{y z}^{2} d_{x y}^{1}$. In the $\{\mathrm{Mo}(\mathrm{O}) \mathrm{Tp} * \mathrm{Cl}\}^{+}$fragment, the oxo ligand is a strong $\partial$-donor, the filled oxygen $p_{x}$ and $p_{y}$ orbitals overlapping with the metal $d_{x z}$ and $d_{y z}$ orbitals, raising them but again leaving the $d_{x y}$ orbital unchanged. The $\mathrm{Mo}(\mathrm{V})$ electronic configuration is therefore $d_{x y}^{1} d_{x z}^{0} d_{y z}^{0}$. In both cases, the $d_{x y}$ orbital is of the correct symmetry for $d_{\pi}-p_{\pi}$ overlap with the bridging ligand.

As we have remarked before ${ }^{12}$, a number of factors combine to make these two metal fragments particularly useful for studying electronic and magnetic interactions between metal centres across a range of bridging ligands designed to allow investigation of the effects of ligand length, conformation and topology. Both systems are (i) redox active,
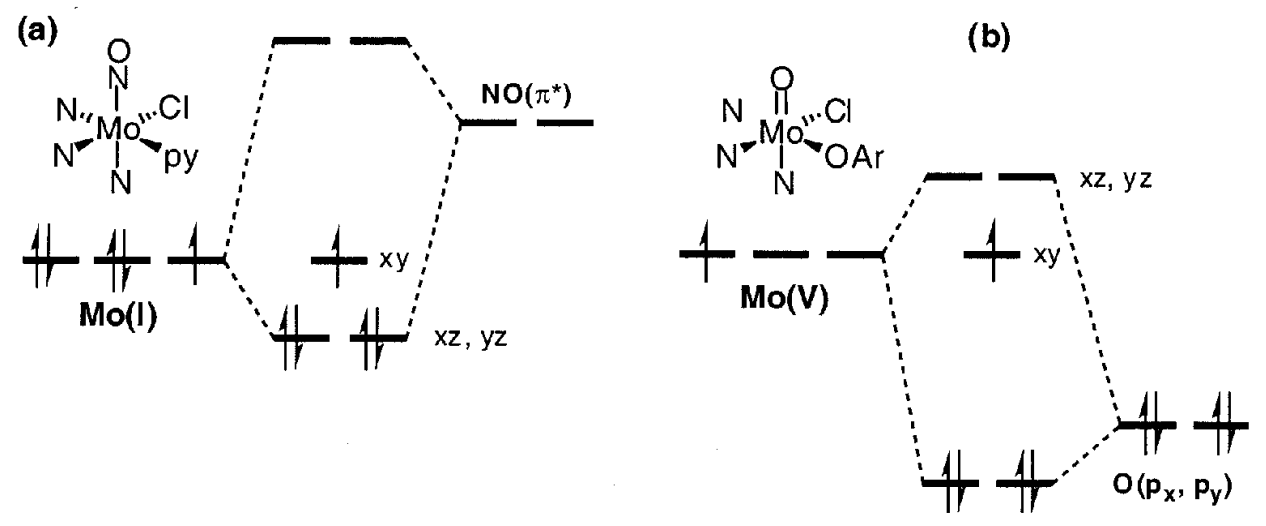

Figure 2. Ground-state electronic configurations for complexes containing (a) $\{\mathrm{Mo}(\mathrm{NO}) \mathrm{Tp} * \mathrm{Cl}\}$ bound to a pyridine ligand, and (b) $\{\mathrm{Mo}(\mathrm{O}) \mathrm{Tp} * \mathrm{Cl}\}^{+}$bound to an aryloxide ligand. 
permitting the study of electronic interactions by voltammetry, and (ii) paramagnetic, enabling the study of magnetic exchange interactions by EPR spectroscopy and magnetic susceptibility measurements. Furthermore, the $\mathrm{Mo}-\mathrm{NO}$ and $\mathrm{Mo}=\mathrm{O}$ groups provide easily identifiable and strong or moderately strong IR absorptions which are very convenient spectroscopic probes for monitoring changes in electronic density at the metal centres.

Within the electron transfer chain involving $\left[\left\{\mathrm{Mo}(\mathrm{NO}) \mathrm{Tp}^{*} \mathrm{Cl}\right\}_{2}(\text { dipy) }]^{z}\right.$ there are two distinct one-electron reduction processes $(z=-1$ and -2$)$ in which the interaction between the metal centres, as measured by the difference between the first and second formation potentials, can be very large: up to $\sim 800 \mathrm{mV}$ with comproportionation constants of $\sim 10^{12}$ in $\mathrm{CH}_{2} \mathrm{Cl}_{2}$ ). However, there are two apparently coincident oxidations, giving a dication. A contrary situation appears to exist for $\left[\{\mathrm{Mo}(\mathrm{O}) \mathrm{Tp} * \mathrm{Cl}\}_{2}\left\{\mathrm{OC}_{6} \mathrm{H}_{4} \mathrm{EC}_{6} \mathrm{H}_{4} \mathrm{O}\right)\right]^{z}$, where reduction seems to involve coincident one-electron process, leading to a dianion, whereas the one-electron oxidations are clearly separate, the interactions again being significant (up to $\sim 1000 \mathrm{mV}$ in $\mathrm{CH}_{2} \mathrm{Cl}_{2}$ ).

In order to interpret these observations, it is necessary to construct a qualitative molecular orbital scheme for the dinuclear species, figure $3{ }^{12}$. For the nitrosyl complexes, the relatively high-energy $d_{x y}$ orbitals lie just below the low-lying $\partial^{*}$ orbitals of the dipyridyl bridging ligand, over which delocalisation can occur. Addition of a further electron to each $d_{x y}$ orbital will raise them in energy even closer to the $\partial^{*}$ level, so that on reduction these $d_{x y}$ electrons are very effectively delocalised over the bridging group. This doubly reduced species can be represented by two extreme forms: [ $\{\mathrm{Mo}(0)\}-\mathrm{L}-$ $\{\mathrm{Mo}(0)\}]$ and $\left[\left\{\mathrm{Mo}(\mathrm{I})-\left(\mathrm{L}^{2-}\right)-\{\mathrm{Mo}(\mathrm{I})\}\right]\right.$ or $\left[\{\mathrm{Mo}(\mathrm{NO})\}^{6}-\mathrm{L}-\{\mathrm{Mo}(\mathrm{NO})\}^{6}\right]$ and $\left[\{\mathrm{Mo}(\mathrm{NO})\}^{5}-\right.$ $\left.\left(\mathrm{L}^{2-}\right)-\{\mathrm{Mo}(\mathrm{NO})\}^{5}\right]$, such an arrangement recognising the well-documented ability of oligo-pyridine ligands to reduce relatively easily. In such a situation the two added electrons will be relatively close to each other, and the electrostatic repulsion will be strong, hence leading to relatively large values of $\Delta E_{f}$. On the other hand, oxidation of the metals, with the concomitant formation of positively charged species, will lower the $d_{x y}$ orbitals away from the $\partial^{*}$ levels so that the $d_{x y}$ electrons are much more metal-localised. Furthermore, the HOMO of the bridging dipyridyl is much lower in energy than the $d_{x y}$

(a)

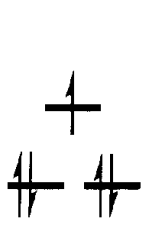

LUMO

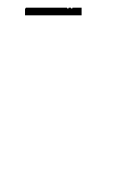

HOMO

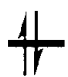

$\operatorname{Mo}(\mathbf{l})$

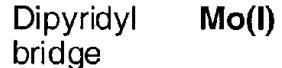

(b)
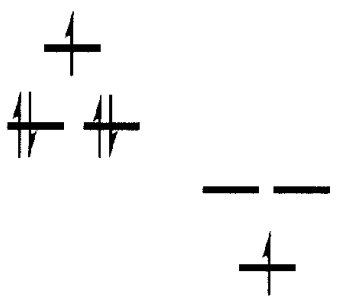

HOMO
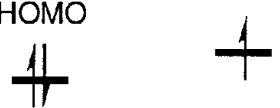

Mo(V)

Mo(V) bridge

Figure 3. Qualitative MO scheme for (a) $\left[\left\{\mathrm{Mo}(\mathrm{NO}) \mathrm{Tp}^{*} \mathrm{Cl}\right\}_{2}(\operatorname{dipy})\right]$ and (b) $[\mathrm{Mo}(\mathrm{O}) \mathrm{Tp} * \mathrm{Cl}\}_{2}$ (diphenolate)] (dipy $\equiv$ generic class of $4,4^{\prime}$-dipyridyl ligands). 
orbitals and therefore cannot participate in stabilising the oxidised species. The doubly oxidised species may be represented as $[\{\mathrm{Mo}(\mathrm{II})\}-\mathrm{L}-\{\mathrm{Mo}(\mathrm{II})\}]$ or $\left[\{\mathrm{Mo}(\mathrm{NO})\}^{4}-\mathrm{L}-\right.$ $\left.\{\mathrm{Mo}(\mathrm{NO})\}^{4}\right]$ and there will be little contribution from the $\left[\{\mathrm{Mo}(\mathrm{I})\}-\left(\mathrm{L}^{2+}\right)-\{\mathrm{Mo}(\mathrm{I})\}\right]$ or $\left[\{\mathrm{Mo}(\mathrm{NO})\}^{5}-\left(\mathrm{L}^{2+}\right)-\{\mathrm{Mo}(\mathrm{NO})\}^{5}\right]$ form.

In the corresponding oxo diphenolato-bridged complexes we drew attention to the significant separations between the two oxidation potentials, and the near or actual coincidence of the reduction processes. In these, the $d_{x y}$ orbital is not far above the HOMO of the bridging ligand, which is relatively high in energy because it carries a double negative charge. Oxidation will lower the $d_{x y}$ orbital further, and the positive charges will therefore be partly delocalised onto the bridging ligand. In contrast, reduction to Mo(IV) will raise the $d_{x y}$ orbitals above the bridging ligand HOMO so that delocalisation is decreased. The bridging ligand LUMO is too high in energy to participate, so the reductions are metal-localised. Hence, for the species $\left[\{\mathrm{Mo}(\mathrm{O}) \mathrm{Tp} * \mathrm{Cl}\}_{2}\right.$ (diphenolate) $]^{2+}$, two extreme canonical forms can be written:

$$
\begin{aligned}
& {\left[\left\{\mathrm{Mo}(\mathrm{VI})-\{\text { diphenolate }\}^{2-}-\{\mathrm{Mo}(\mathrm{VI})\}\right]\right. \text { and }} \\
& {\left[\left\{\mathrm{Mo}(\mathrm{V})-\{\text { diphenolate }\}^{0}-\{\mathrm{Mo}(\mathrm{V})\}\right] .\right.}
\end{aligned}
$$

Note that $\{\text { diphenolate }\}^{0}$ is the oxidised form of $\{\text { diphenolate }\}^{2-}$, i.e. a quinone. That oxidation of the diphenolato ligand could play a significant role in the description of these oxidised complexes is consistent with the known propensity of para-substituted diphenols to be oxidised to quinones and, as we shall see later, has important consequences for the behaviour of this class of complex.

\section{Dinuclear nitrosyl complexes}

The dinuclear complexes $\left[\left\{\mathrm{Mo}(\mathrm{NO}) \mathrm{Tp}^{*} \mathrm{Cl}\right\}_{2}\right.$ (py-E-py)] shown in figure 1 are prepared by reacting $\left[\mathrm{Mo}(\mathrm{NO}) \mathrm{Tp}^{*} \mathrm{Cl}_{2}\right]$ with the appropriate dipyridyl in toluene in the presence of $\mathrm{NEt}_{3}{ }^{17}$. The molecular structure of the complex where $E=-(\mathrm{CH}=\mathrm{CH})_{4}-$ was determined crystallographically, and this confirmed that the pyridine rings and the polyene chain are essentially coplanar and that there is conjugation between the rings and the chain. Furthermore, the structural co-ordinates indicate that there is likely to be reasonably good overlap between the metal $d_{x y}$ and pyridine $\partial$-orbitals. These dinuclear complexes are strongly solvatochromic, consistent with the highly polarising nature of the molybdenum nitrosyl group ${ }^{18}$.

As described above, these complexes are oxidised in a two-electron step, but are reduced sequentially in two one-electron processes, the separation between the formation potentials for the mono- and dianion being dependent mainly on the length of the polyene chain. Spectroelectrochemical studies of mononuclear and dinuclear nitrosyl complexes of this type reveal the evolution of strong bands in the NIR region as the monoanion is generated. This is illustrated in figure 4, which shows the behaviour of $[\mathrm{Mo}(\mathrm{NO}) \mathrm{Tp} * \mathrm{Cl}(\mathrm{py})]$ on reduction in dichloromethane. Of the original metal-to-ligand charge-transfer (MLCT) bands, the one at highest energy almost doubles in intensity but, more dramatically, a strong new band grows up at $804 \mathrm{~nm}$. This is also a MLCT absorption, occurring at lower energy because the energy of the metal-centred $d ð$ orbitals increases on reduction bringing them closer to the ligand-centred acceptor LUMO orbitals ${ }^{19}$. Even more remarkable events occur on reduction of the dinuclear species 
$\left[\left\{\mathrm{Mo}(\mathrm{NO}) \mathrm{Tp}{ }^{*} \mathrm{Cl}\right\}_{2}\left\{\mathrm{py}(\mathrm{CH}=\mathrm{CH})_{3} \mathrm{py}\right\}\right]$ (figure 5) ${ }^{17}$. In all cases, very strong charge transfer bands evolve, but further into the NIR region than in the mononuclear species (table 1). The intensities and structure of these bands are characteristic of polyene chromophores, but the transitions are at lower energies than would normally be expected. This is probably because the LUMO of the neutral complex has significant ligand character, and the shift to lower energy occurs probably because the separation of the HOMO and LUMO in the neutral molecule is much larger than the separation of the LUMO and the second lowest unoccupied orbital.

Spectroelectrochemical studies of $\left[\{\mathrm{Mo}(\mathrm{NO}) \mathrm{Tp} * \mathrm{Cl}\}_{2}\left(4,4^{\prime}\right.\right.$-bipy $\left.)\right] \quad\left(4,4^{\prime}\right.$-bipy $=4,4-$ dipyridyl) show that the behaviour of this compound is different from the related

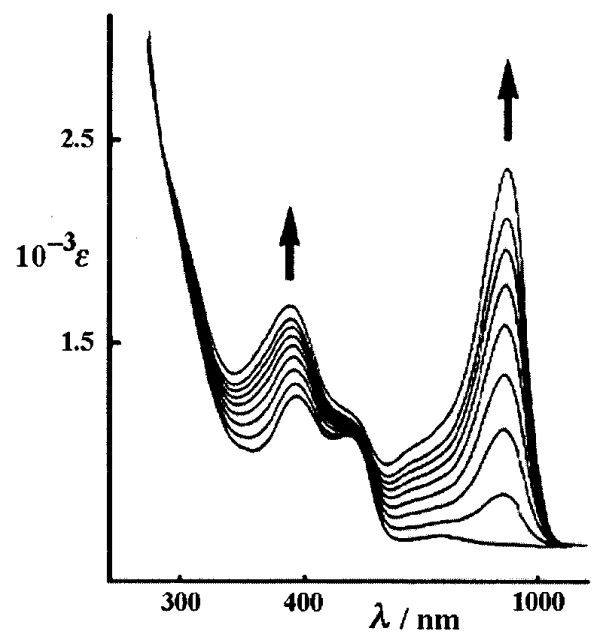

Figure 4. Spectroelectrochemistry of $[\mathrm{Mo}(\mathrm{NO}) \mathrm{Tp} * \mathrm{Cl}(\mathrm{py})]\left(\varepsilon\right.$ in $\left.\mathrm{dm}^{3} \mathrm{~mol}^{-1} \mathrm{~cm}^{-1}\right)$.

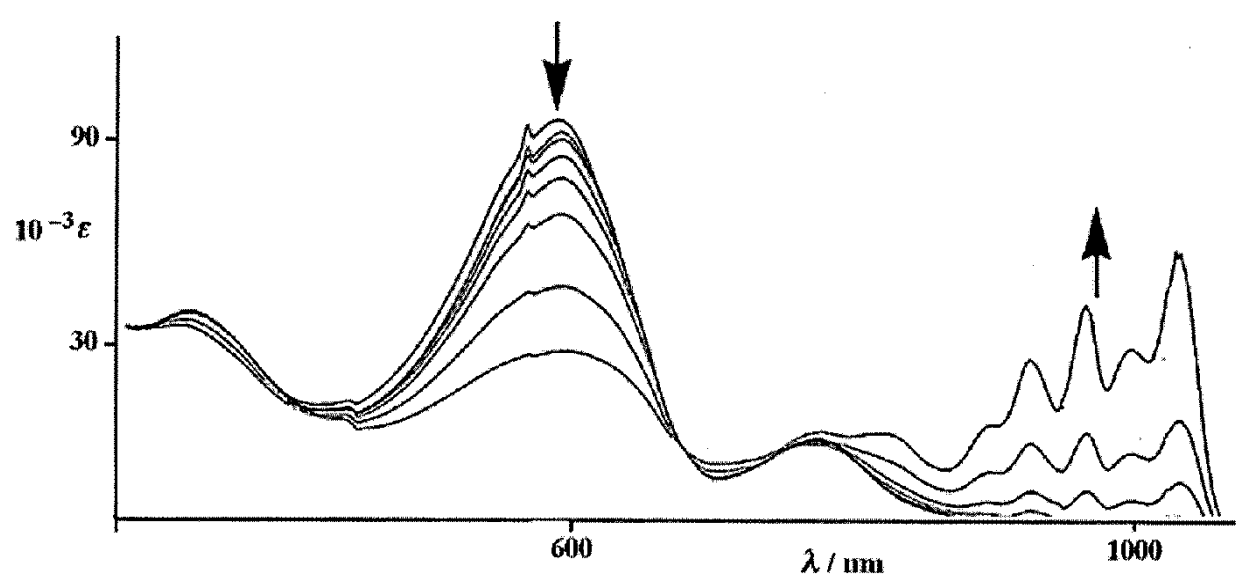

Figure 5. Spectroelectrochemistry of $\left[\{\mathrm{Mo}(\mathrm{NO}) \mathrm{Tp} * \mathrm{Cl}\}_{2}\left\{\mathrm{py}(\mathrm{CH}=\mathrm{CH})_{3} \mathrm{py}\right\}\right](\varepsilon$ in $\left.\mathrm{dm}^{3} \mathrm{~mol}^{-1} \mathrm{~cm}^{-1}\right)$. 
Table 1. Electronic spectra of neutral and reduced dinuclear nitrosyl complexes.

\begin{tabular}{|c|c|}
\hline Complex & $\lambda_{\max } / \mathrm{nm}\left(\varepsilon / 10^{-3} \mathrm{dm}^{3} \mathrm{~mol}^{-1} \mathrm{~cm}^{-1}\right)$ \\
\hline$[\mathrm{Mo}(\mathrm{NO}) \mathrm{Tp} * \mathrm{Cl}(\mathrm{py})]$ & $409(1 \cdot 5), 467(1 \cdot 3), 620(0 \cdot 2)$ \\
\hline$[\mathrm{Mo}(\mathrm{NO}) \mathrm{Tp} * \mathrm{Cl}(\mathrm{py})]^{-}$ & $399(2 \cdot 7), 462(1 \cdot 5), 804(4 \cdot 4)$ \\
\hline$\left[\{\mathrm{Mo}(\mathrm{NO}) \mathrm{Tp} * \mathrm{Cl}\}\left\{\mathrm{py}(\mathrm{CH}=\mathrm{CH})_{2} \mathrm{py}\right\}\right.$ & $\begin{array}{l}506(16 \cdot 8), 563(21 \cdot 9), 699(35 \cdot 9), 781(40 \cdot 4), \\
\quad 952(48 \cdot 8), 1086(57 \cdot 2)\end{array}$ \\
\hline$\left[\{\mathrm{Mo}(\mathrm{NO}) \mathrm{Tp} * \mathrm{Cl}\}\left\{\mathrm{py}(\mathrm{CH}=\mathrm{CH})_{3} \mathrm{py}\right\}\right.$ & $\begin{array}{c}534(2 \cdot 7), 595(26 \cdot 6), 724(28 \cdot 0), 793(48 \cdot 7) \\
917(67 \cdot 8), 1020(70 \cdot 0), 1212(97 \cdot 3)\end{array}$ \\
\hline$\left[\left\{\mathrm{Mo}(\mathrm{NO}) \mathrm{Tp}^{*} \mathrm{Cl}\right\}\left\{\mathrm{py}(\mathrm{CH}=\mathrm{CH})_{4} \mathrm{py}\right.\right.$ & $\begin{array}{l}588(39 \cdot 3), 628(57 \cdot 0), 666(49 \cdot 0), 806(63 \cdot 8), \\
\quad 892(64 \cdot 8), 1025(70 \cdot 6), 1282(65 \cdot 7)\end{array}$ \\
\hline$\left[\{\mathrm{Mo}(\mathrm{NO}) \mathrm{Tp} * \mathrm{Cl}\}_{2}(\right.$ bipy $\left.)\right]$ & $355(6 \cdot 8), 558(4 \cdot 5)$ \\
\hline$\left[\left\{\mathrm{Mo}(\mathrm{NO}) \mathrm{Tp}^{*} \mathrm{Cl}\right\}_{2}(\text { bipy })\right]^{-}$ & $355(6 \cdot 0), 432(8 \cdot 3), 547(10 \cdot 3), 870(21 \cdot 3)$ \\
\hline$\left[\left\{\mathrm{Mo}(\mathrm{NO}) \mathrm{Tp}^{*} \mathrm{Cl}\right\}_{2}(\text { bipy })\right]^{2-}$ & $\begin{array}{l}353(10 \cdot 3), 431(9 \cdot 0), 493(8 \cdot 2), 547(7 \cdot 1), \\
\quad 1189(24 \cdot 8)\end{array}$ \\
\hline
\end{tabular}

dipyridyl polyenes. In DMF at $-20^{\circ} \mathrm{C}$, reduction of the neutral species to the monoanion is accompanied by spectral changes very similar to those derived from mononuclear species, e.g. $\left[\mathrm{Mo}(\mathrm{NO}) \mathrm{Tp}^{*} \mathrm{Cl}(\mathrm{py})\right]^{-}$, implying that there is limited delocalisation onto the dipyridyl ligand, but little interaction between the two metal centres. However, as $\left[\left\{\mathrm{Mo}(\mathrm{NO}) \mathrm{Tp} \mathrm{Cl}^{*}\right\}_{2}\left(4,4^{\prime} \text {-bipy }\right)\right]^{2-}$ evolves, NIR transitions appear, the final spectrum being quite similar to those of related monoanions. We interpret this to mean that in the neutral and monoanionic species the dihedral angle between the two pyridine rings is significant, hindering cross-molecule delocalisation, but in the dianion the two rings approach coplanarity, thereby facilitating substantial delocalisation.

\section{Dinuclear oxomolybdenum diphenolato complexes}

The species $\left[\left\{\mathrm{Mo}(\mathrm{O}) \mathrm{Tp} \mathrm{p}^{*} \mathrm{Cl}_{2}\left(\mathrm{OC}_{6} \mathrm{H}_{4} \mathrm{EC}_{6} \mathrm{H}_{4} \mathrm{O}\right)\right]\right.$ (figure 1) were prepared by reaction of $\left[\mathrm{Mo}(\mathrm{O}) \mathrm{Tp}^{*} \mathrm{Cl}_{2}\right]$ with the appropriate diphenolate dianion. As described above, they may be oxidised sequentially to a mono- and a dianion, and reduced, usually in a two electron step, to a dianion. The structures of several of these dinuclear species have been determined crystallographically, viz. the 1,3- and 1,4-isomers of $\left[\left\{\mathrm{Mo}(\mathrm{O}) \mathrm{Tp}^{*} \mathrm{Cl}\right\}_{2}\right.$ $\left.\left(\mathrm{OC}_{6} \mathrm{H}_{4} \mathrm{O}\right)\right]^{20}$ and $\left[\left\{\mathrm{Mo}(\mathrm{O}) \mathrm{Tp}^{*} \mathrm{Cl}\right\}_{2}\left(\mathrm{OC}_{6} \mathrm{H}_{4} \mathrm{EC}_{6} \mathrm{H}_{4} \mathrm{O}\right)\right]$, where $E=\mathrm{N}=\mathrm{N}$ or $\mathrm{CO}^{21}$.

Electrochemical examination of this group of complexes revealed that the connecting group $E$ has a significant influence on the separation between the first and second oxidation potentials ${ }^{21,22}$. The efficiency of $E$ in facilitating delocalisation across the complexes is thienyl > ethenyl > phenyl, the thienyl units being particularly effective in maintaining large separations between the potentials over long distances. An ethenyl spacer was almost as effective as an ethynyl spaces at mediating electronic interactions, but the azo spacer, $\mathrm{N}=\mathrm{N}$, is significantly worse. As with the dipyridyl nitrosyl complexes, interaction between the two redox centres diminishes significantly as the pathway between them lengthens.

Spectroelectrochemical studies provided more revealing information about the nature of the oxidised species, however ${ }^{22}$. The lowest energy electronic transition in neutral mononuclear species $[\mathrm{Mo}(\mathrm{O}) \mathrm{Tp} * \mathrm{Cl}(\mathrm{OAr})]$ is a phenolate $\rightarrow$ Mo LMCT process, occurring in the region $500-700 \mathrm{~nm}$ (see figure 6 for a typical example). On oxidation, this evolves into two stronger peaks, one at $\sim 550 \mathrm{~nm}$, and the other close to the near-IR region, between 700 and $900 \mathrm{~nm}$, both being enhanced LMCT processes. 


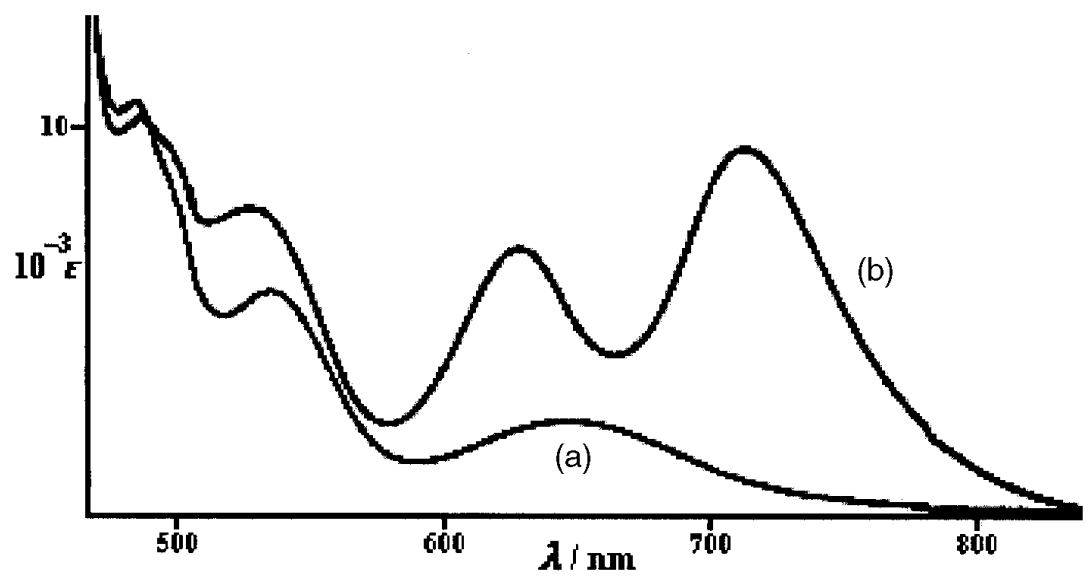

Figure 6. Electronic spectra of (a) $\left[\mathrm{Mo}(\mathrm{NO}) \mathrm{Tp} * \mathrm{Cl}\left(\mathrm{OC}_{6} \mathrm{H}_{4} \mathrm{OMe}-p\right)\right]$ and (b) $\left[\mathrm{Mo}(\mathrm{NO}) \mathrm{Tp}^{*} \mathrm{Cl}\left(\mathrm{OC}_{6} \mathrm{H}_{4} \mathrm{OMe}-p\right)\right]^{+}\left(\varepsilon\right.$ in $\left.\mathrm{dm}^{3} \mathrm{~mol}^{-1} \mathrm{~cm}^{-1}\right)$.

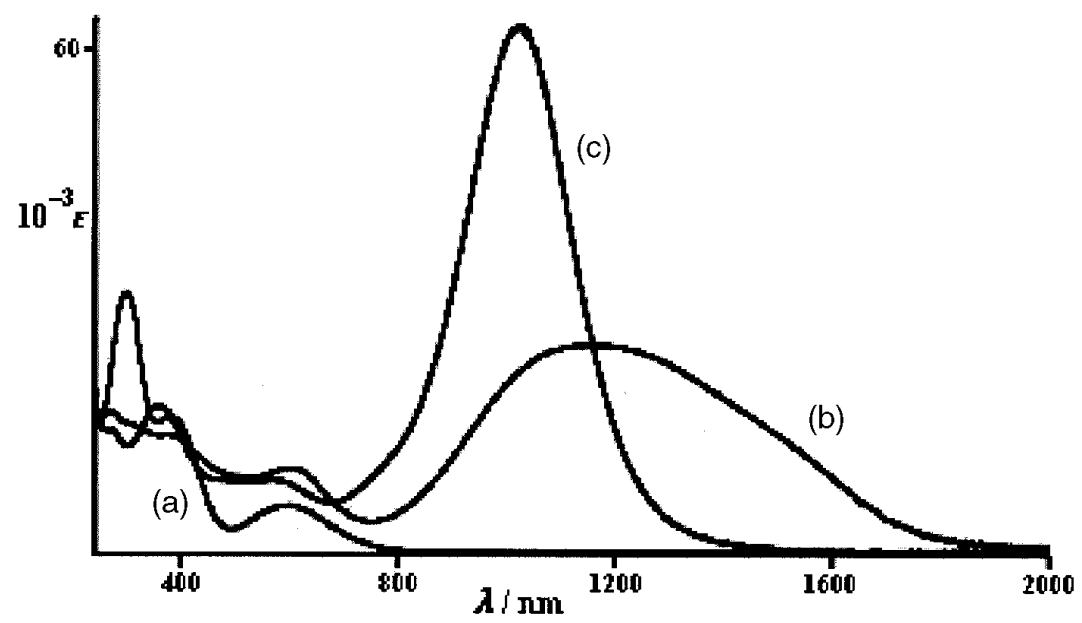

Figure 7. Electronic spectra of (a) $\left[\{\mathrm{Mo}(\mathrm{NO}) \mathrm{Tp} * \mathrm{Cl}\}_{2}\left\{\mathrm{O}\left(\mathrm{C}_{6} \mathrm{H}_{4}\right)_{3} \mathrm{O}\right\}\right]$, (b) $\left[\{\mathrm{Mo}(\mathrm{NO}) \mathrm{Tp} * \mathrm{Cl}\}_{2}\left\{\mathrm{O}\left(\mathrm{C}_{6} \mathrm{H}_{4}\right)_{3} \mathrm{O}\right\}\right]^{+}$and (c) $\left[\{\mathrm{Mo}(\mathrm{NO}) \mathrm{Tp} * \mathrm{Cl}\}_{2}\left\{\mathrm{O}\left(\mathrm{C}_{6} \mathrm{H}_{4}\right)_{3} \mathrm{O}\right\}\right]^{2+}(\varepsilon$ in $\left.\mathrm{dm}^{3} \mathrm{~mol}^{-1} \mathrm{~cm}^{-1}\right)$.

In the dinuclear species the situation seems to be broadly similar, as shown in figure 7. However, the lowest energy transition in the monocationic species occurs much further into the near-IR region, the exact position being determined by the nature of the bridging group. So, in the group of complexes where $E=\left(\mathrm{C}_{6} \mathrm{H}_{4}\right)_{n}$, this NIR transition appears at $\lambda_{\max }=1096,1131$ and $1047 \mathrm{~nm}$ for $n=0,1$ and 2, respectively. On further oxidation to the dication, this transition is slightly blue-shifted, to $\lambda_{\max }=1017,1015$ and $1033 \mathrm{~nm}$, respectively. 
It is tempting to make the assumption that these oxidative processes are metal-based, the mono- and dicationic species being formally described as $\left\{\mathrm{Mo}^{\mathrm{VI}}-\right.$ (dianionic bridge)$\left.\mathrm{Mo}^{\mathrm{V}}\right\}$ and $\left\{\mathrm{Mo}^{\mathrm{VI}}-(\right.$ dianionic bridge $\left.)-\mathrm{Mo}^{\mathrm{VI}}\right\}$ respectively. This is indicated in figure 8 , pathway (i). However, there is an alternative way of looking at this situation, as shown by pathway (ii) in the same figure.

Instead of metal-based oxidation, one can invoke ligand oxidation:

$$
\begin{aligned}
& {\left[\mathrm{Mo}^{\mathrm{V}}-(\text { diphenolate })-\mathrm{Mo}^{\mathrm{V}}\right]^{2+} \square} \\
& {\left[\mathrm{Mo}^{\mathrm{V}}-(\text { semiquinone })-\mathrm{Mo}^{\mathrm{V}}\right]^{1+} \square\left[\mathrm{Mo}^{\mathrm{V}}-\text { (quinone) }-\mathrm{Mo}^{\mathrm{V}}\right]}
\end{aligned}
$$

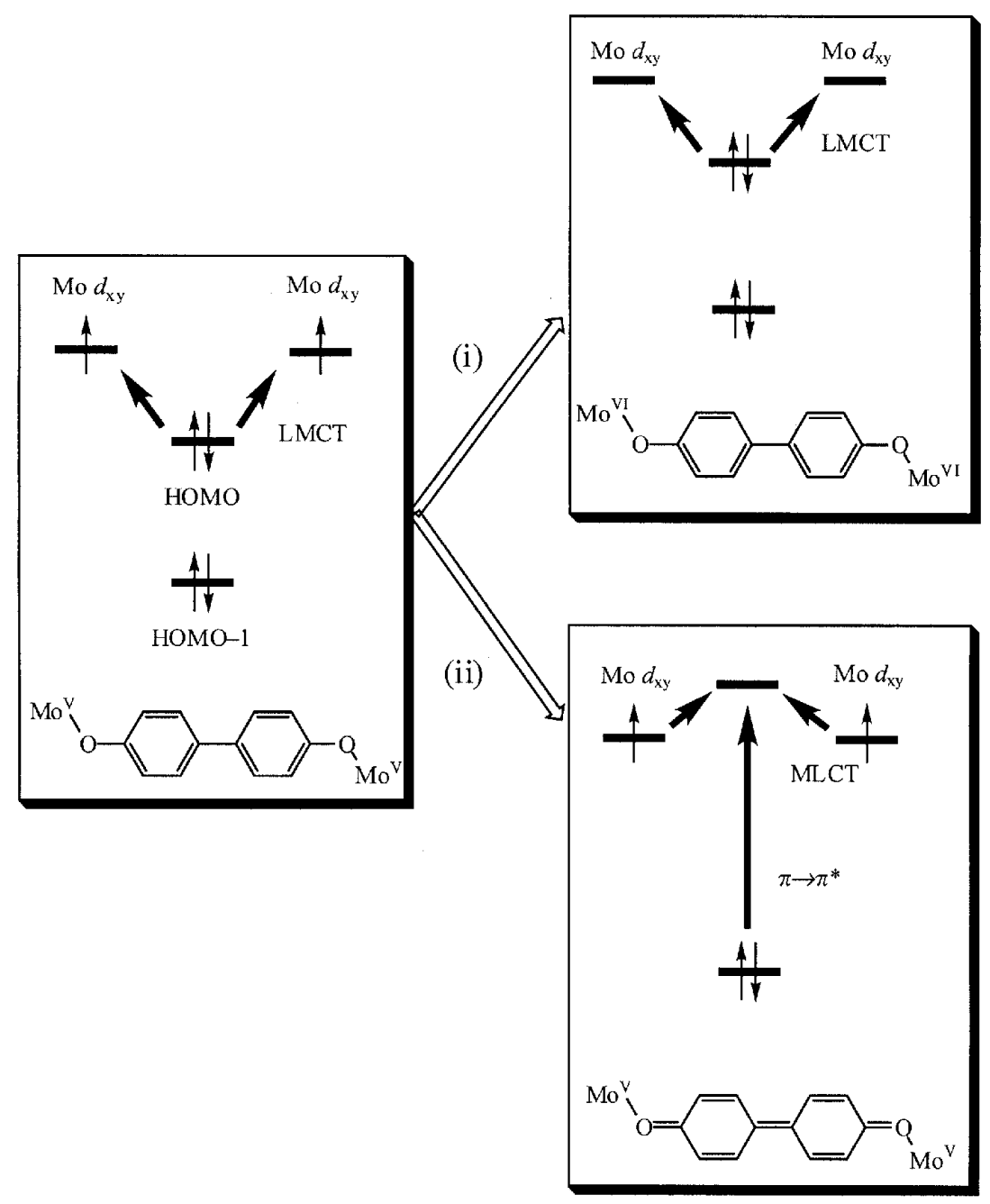

Figure 8. Generation of the doubly oxidized forms of dinuclear oxomolybdenum complexes arising from metal-centred oxidation, pathway (i), and ligand-centred oxidations, pathway (ii); and accompanying electronic transitions. 
If such ligand oxidation was to occur, we would expect semiquinone and then quinonebased $\partial \rightarrow \partial^{*}$ transitions to appear. From a wealth of magnetic and EPR spectroscopic data, it is quite clear that the neutral precursors contain two oxomolybdenum(V) groups connected by a diphenolato bridge ${ }^{20-22}$. According to the MO scheme shown in figure 3 (b), the highest energy occupied orbitals are the singly occupied $d_{x y}$ on each metal, the bridging ligand HOMO lying just below this. We would therefore expect the first oxidation to be metal-based, although it would only require a small change in the relative energies of ligand frontier orbitals following the first oxidation to change this picture for subsequent oxidations. Such behaviour would constitute 'non-innocence'. The spectral behaviour of $\left[\{\mathrm{Mo}(\mathrm{O}) \mathrm{Tp} * \mathrm{Cl}\}_{2}\left\{\mathrm{O}\left(\mathrm{C}_{6} \mathrm{H}_{4}\right)_{n} \mathrm{O}\right\}\right]$ on oxidation is very similar to that of the mononuclear species $[\mathrm{Mo}(\mathrm{O}) \mathrm{Tp} * \mathrm{Cl}(\mathrm{OAr})]$, i.e. the strong near-IR transitions are typical of phenolate $\rightarrow \mathrm{Mo}^{\mathrm{VI}}$ LMCT processes, and this is supported by ZINDO calculations on the doubly oxidised dinuclear species. It is also clear that the spectra of $\left[\{\mathrm{Mo}(\mathrm{O}) \mathrm{Tp} * \mathrm{Cl}\}_{2}\right.$ $\left.\left\{\mathrm{O}\left(\mathrm{C}_{6} \mathrm{H}_{4}\right)_{n} \mathrm{O}\right\}\right]^{n+}$ are quite different to those of related free polyphenylene quinones, whose $\partial \rightarrow \partial^{*}$ are would be much higher in energy. Furthermore, the absorption maxima for the free quinone series becomes progressively red-shifted as the quinone lengthens, which does not happen in the spectra of $\left[\{\mathrm{Mo}(\mathrm{O}) \mathrm{Tp} * \mathrm{Cl}\}_{2}\left\{\mathrm{O}\left(\mathrm{C}_{6} \mathrm{H}_{4}\right)_{n} \mathrm{O}\right\}\right]^{2+}$, and while $\lambda_{\max }$ for the latter is similar in energy for both the mono- and dications, free semiquinones and related quinones behave quite differently. So it seems clear that oxidation of $\left[\left\{\mathrm{Mo}(\mathrm{O}) \mathrm{Tp} \mathrm{P}^{*} \mathrm{Cl}\right\}_{2}\left\{\mathrm{O}\left(\mathrm{C}_{6} \mathrm{H}_{4}\right)_{n} \mathrm{O}\right\}\right]$ is predominantly a metal-based process, i.e. pathway (i) in figure 8 .

The spectroelectrochemical behaviour of $\left[\{\mathrm{Mo}(\mathrm{O}) \mathrm{Tp} * \mathrm{Cl}\}_{2}\left(\mathrm{OC}_{6} \mathrm{H}_{4} \mathrm{~N}=\mathrm{NC}_{6} \mathrm{H}_{4} \mathrm{O}\right]\right.$ (figure 9) contrasts with that of $\left[\left\{\mathrm{Mo}(\mathrm{O}) \mathrm{Tp}^{*} \mathrm{Cl}\right\}_{2}\left\{\mathrm{O}\left(\mathrm{C}_{6} \mathrm{H}_{4}\right)_{n} \mathrm{O}\right\}\right]$. The spectrum of $\left[\left\{\mathrm{Mo}(\mathrm{O}) \mathrm{Tp}^{*} \mathrm{Cl}\right\}_{2} \mathrm{OC}_{6} \mathrm{H}_{4} \mathrm{~N}=\mathrm{NC}_{6} \mathrm{H}_{4} \mathrm{O}\right]^{+}$exhibits a principal absorption maximum at

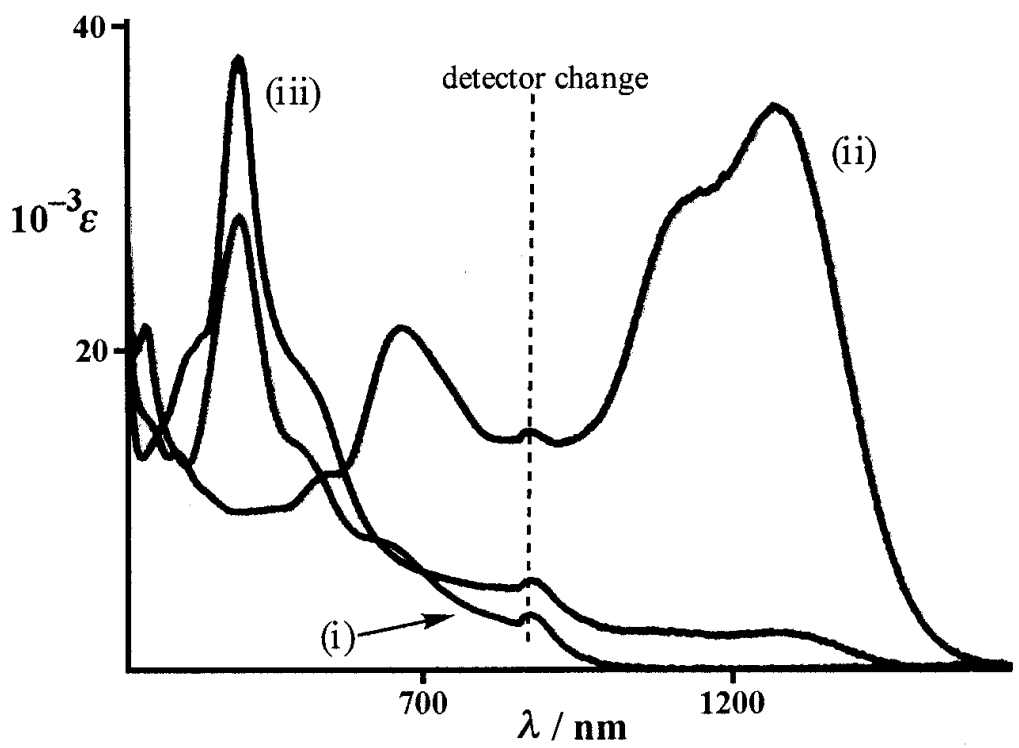

Figure 9. Electronic spectra of $\left[\{\mathrm{Mo}(\mathrm{O}) \mathrm{Tp} * \mathrm{Cl}\}_{2} \mathrm{OC}_{6} \mathrm{H}_{4} \mathrm{~N}=\mathrm{NC}_{6} \mathrm{H}_{4} \mathrm{O}\right]^{n}$ : (i) $n=0$; (ii) $n=+1$; (iii) $n=+2$. 
$\lambda_{\max }=1268 \mathrm{~nm}$, characteristic of a phenolato $\rightarrow \mathrm{Mo}^{\mathrm{VI}}$ LMCT process, whereas that of $\left[\left\{\mathrm{Mo}(\mathrm{O}) \mathrm{Tp}^{*} \mathrm{Cl}\right\}_{2} \mathrm{OC}_{6} \mathrm{H}_{4} \mathrm{~N}=\mathrm{NC}_{6} \mathrm{H}_{4} \mathrm{O}\right]^{2+}$ has $\lambda_{\max }=409 \mathrm{~nm}$, suggesting that the second oxidation leads to the formation of a bridging quinone. The occurrence of this intense transition in the visible region in the dication is more like a $\partial \rightarrow \partial^{*}$ transition of a free quinone than a phenolate $\rightarrow \mathrm{Mo}{ }^{\mathrm{VI}}$ transition which, as we have seen, occurs in the nearIR region. ZINDO calculations on this and closely related species are broadly consistent with this view. So the oxidative behaviour of $\left[\left\{\mathrm{Mo}(\mathrm{O}) \mathrm{Tp}^{*} \mathrm{Cl}\right\}_{2}\left\{\mathrm{O}\left(\mathrm{C}_{6} \mathrm{H}_{4}\right)_{n} \mathrm{O}\right\}\right]$ is significantly different to that of $\left[\{\mathrm{Mo}(\mathrm{O}) \mathrm{Tp} * \mathrm{Cl}\}_{2} \mathrm{OC}_{6} \mathrm{H}_{4} \mathrm{~N}=\mathrm{NC}_{6} \mathrm{H}_{4} \mathrm{O}\right]$ as a result of an internal charge redistribution associated with the second oxidation. In other words, oneelectron oxidation of $\left\{\mathrm{Mo}^{\mathrm{VI}}-(\right.$ diphenolate $\left.)-\mathrm{Mo}^{\mathrm{V}}\right\}$ affords $\left\{\mathrm{Mo}^{\mathrm{VI}}-(\right.$ diphenolate $\left.)-\mathrm{Mo}^{\mathrm{VI}}\right\}$ with the former but $\left\{\mathrm{Mo}^{\mathrm{V}}\right.$-(quinone)-Mo $\left.\mathrm{Mo}^{\mathrm{V}}\right\}$ with the latter. This form of internal charge redistribution was mentioned in the Introduction, particularly in connection with the catecholate complexes of nickel and vanadium, but its occurrence in systems containing monodentate bridging arene-diolato ligands has not been reported before, and is clear evidence of 'non-innocent' behaviour.

\section{Magnetic properties of dinuclear molybdenum complexes}

The EPR spectra of dinuclear molybdenum nitrosyl complexes of the type shown in figure 1 provided the first evidence that magnetic exchange was an important feature of this class of compounds. About $75 \%$ of the isotopes of molybdenum have a nuclear spin $I=0$, the remaining $25 \%$ having $I=5 / 2$. This means that EPR spectrum of a molybdenum complex having one unpaired electron will be comprised singlet $(75 \%$ of the total intensity) overlapped by a sextet (25\% of the total intensity) at the same $g$-value, and for species containing the $\{\mathrm{Mo}(\mathrm{NO})\}^{2+}$ as well as the $\{\mathrm{Mo}(\mathrm{O})\}^{3+}$ core, the hyperfine coupling constant $A_{\mathrm{Mo}}$ is $\sim 5.0 \mathrm{mT}^{12}$. However, when the unpaired spins are coupled to two molybdenum nuclei, the spectrum consists of a singlet $(I=0, I=0$ nuclear spin combination, $56 \%$ probability), a sextet $(I=5 / 2, \quad I=0,38 \%)$ and a 1:2:3:4:5:6:5: 4:3:2:1 undecet $(I=5 / 2, I=5 / 2,6 \%)$ superimposed on each other, with the hyperfine coupling essential halved, to $\sim 2.5 \mathrm{mT}$. This effect arises in a dinuclear complex containing two unpaired electrons, such as these being discussed here, via magnetic exchange interaction between the electron spins localised on individual metal centres, such that $|J| \square A_{\mathrm{Mo}}$, where $J$ is the energy of the exchange interaction and $A_{\mathrm{Mo}}$ is the energy of the electron-nuclear hyperfine interactions ${ }^{23}$. Such 'exchange coupled' spectra are well-documented in nitroxide diradicals, where coupling of both electrons to both nitrogen nuclear spins occurs, even across saturated spacers where there is no possibility of delocalisation of the electrons ${ }^{23}$. The energy of the hyperfine interaction is very small, the coupling between a single electron localised on one molybdenum centre $(5.0 \mathrm{mT})$ being less than $0.01 \mathrm{~cm}^{-1}$, which corresponds to an exchange interaction far too small to be measured by magnetic susceptibility methods. So even a very weak magnetic exchange interaction can give rise to an exchange-coupled spectrum. In addition, the sign of $J$ has no influence on the spectrum at ambient temperatures: ferromagnetic and antiferromagnetic interactions will give the same spectrum as long as $|J|$ is above the very small lower limit.

All of the dinuclear nitrosyl complexes shown in figure 1 exhibited an exchangedcoupled spectrum indicating that $|J| \square A_{\mathrm{Mo}}$ and $A_{\mathrm{Mo}} 2.5 \mathrm{mT}$. If $A_{\mathrm{Mo}} 5.0 \mathrm{mT}$ in dinuclear species it would be clear that the unpaired spins are isolated on each metal centre, and there is no magnetic exchange. However, intermediate situations could occur 
where $|J| \quad A_{\mathrm{Mo}}$, the EPR spectra then having a second order appearance typical of weak exchange. Such situations arise when the bridging ligands are very long, or when there is a twist in the bridge, which occurs when $\mathrm{C}_{6} \mathrm{H}_{4}-\mathrm{C}_{6} \mathrm{H}_{4}$ groups are incorporated ${ }^{24}$.

The EPR spectra of mononuclear $\left[\mathrm{Mo}(\mathrm{O}) \mathrm{Tp} \mathrm{p}^{*} \mathrm{Cl}(\mathrm{OPh})\right]$ also consisted of a superimposed singlet and sextet with $A_{\mathrm{Mo}} 5.0 \mathrm{mT}$, while the dinuclear species with relatively long bridging ligands (e.g. $\left.\left(\mathrm{C}_{6} \mathrm{H}_{4}\right)_{3},(\mathrm{CH}=\mathrm{CH})_{3}\right)$ were like their nitrosyl counterparts, consisting of a superimposed singlet, sextet and undecet, and $A_{\mathrm{Mo}} \quad 2.5 \mathrm{mT}$. With shorter ligands, the room-temperature spectra were broad and uninformative, except that a half-field $\Delta m_{s}=2$ transition was detectable at $77 \mathrm{~K}$, which provided further evidence of magnetic exchange.

As mentioned above, while it was clear that magnetic exchange could occur, the EPR spectral evidence could not provide information concerning the sign or magnitude of $J$. This could only be obtained by solid state magnetic susceptibility measurements, which have been made of a wide range of dinuclear nitrosyl and oxo molybdenum complexes. Some data are given in table 2.

An inspection of the data obtained from the dipyridyl systems shows that there is an alternation in the sign of $J$ as the bridging ligand substitution pattern changes from $4,4^{\prime}$ through $4,3^{\prime}$ to $3,3^{\prime}$. A similar situation occurs with the 1,4 and 1,3-diphenolato species. These results show that the magnetic interaction switches from antiferromagnetic to

Table 2. Exchange coupling constants as a function of bridging ligand.

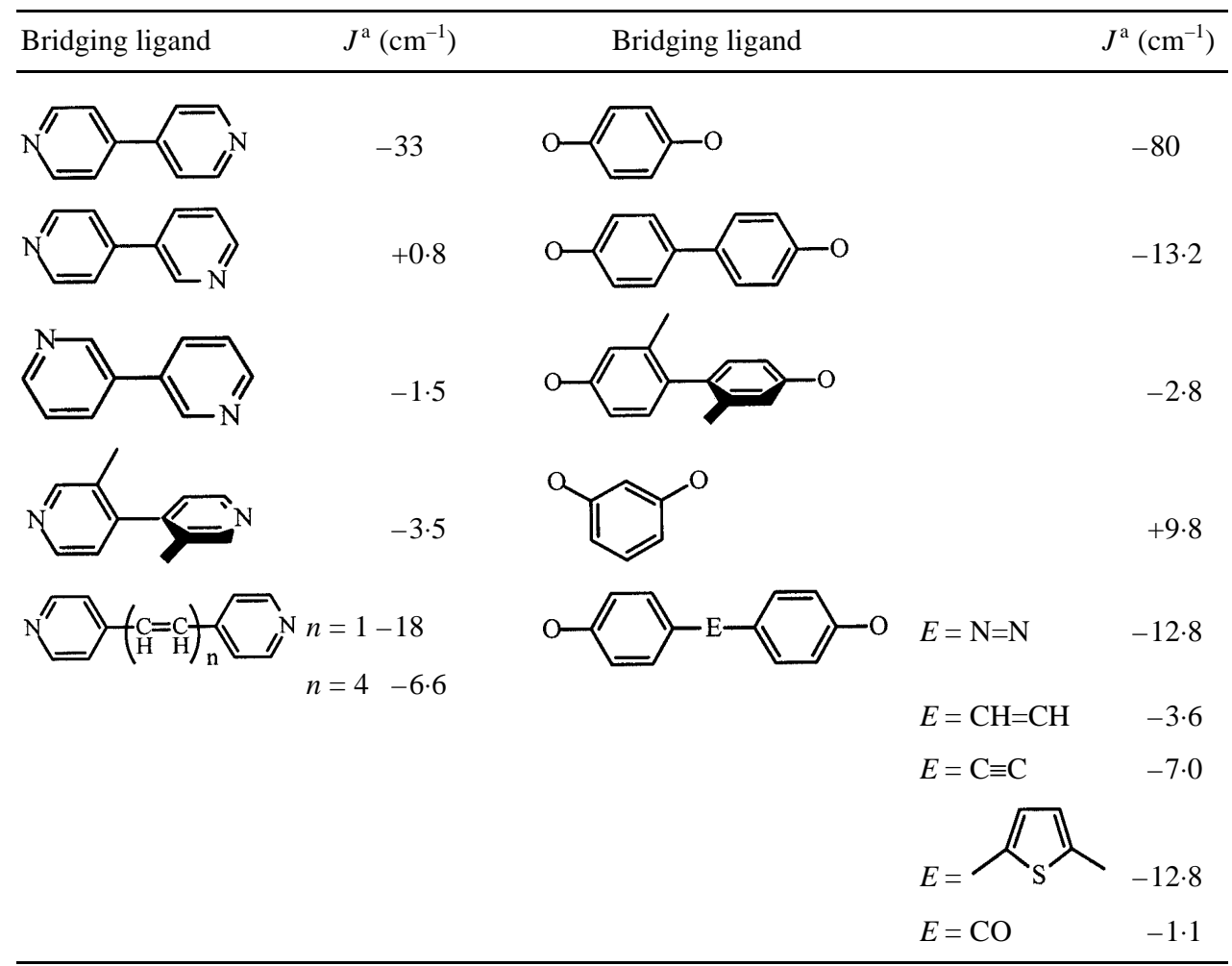

${ }^{a} J$ determined using the exchange spin Hamiltonian in the form $H=-J\left(\mathbf{S}_{1} \mathbf{S}_{2}\right)$ 


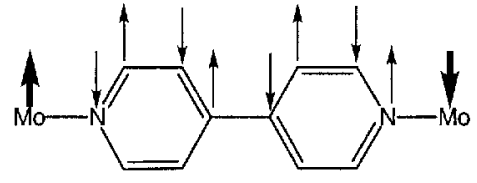

Even atom pathway $\equiv$ antiferromagnetism

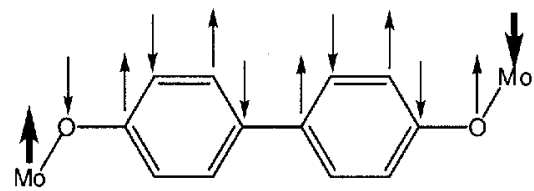

Even atom pathway $\equiv$ antiferromagnetism

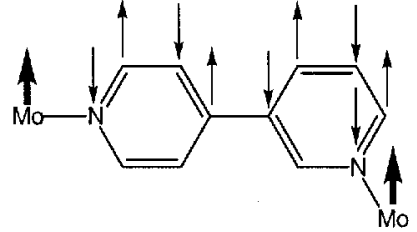

Odd atom pathway $\equiv$ ferromagnetism

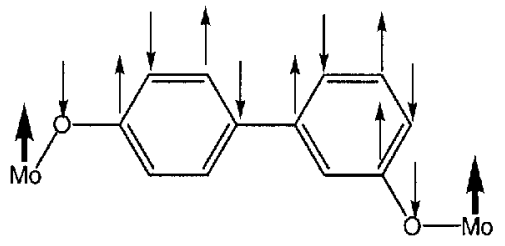

Odd atom pathway $\equiv$ ferromagnetism

Figure 10. The spin-polarisation mechanism over dipyridyl and 4,4'-diphenolato ligands.

ferromagnetic as the number of atoms in the pathway between the interacting spins changes from even to odd. This strongly indicates a spin-polarisation mechanism for propagation of the exchange interaction, as shown in figure 10, a situation which is consistent with the spin exchange interaction detected by EPR spectroscopy. The spinpolarisation mechanism arises from the Longuet-Higgins molecular orbital model for conjugated alternant hydrocarbons ${ }^{25}$, which results in ferromagnetic coupling between two radicals separated by an $m$-phenylene bridge (odd atom pathway).

The results in table 2 also show that $J$ is dependent on the conformation of the bridging ligand. Comparing the data obtained from the 4,4'-dipyridyl-bridged complex, where there is a twist of $\sim 26^{\circ}$ between the two pyridine rings) with that from the $2,2^{\prime}$-dimethyl4,4-dipyridyl analogue, where the twist is $90^{\circ}$, it is clear that the magnitude of $J$ decreases by about $90 \%$ as the two halves of the bridging ligand approach orthogonality. This is further evidence, if any is needed, that the spin-polarisation is propagated via the delocalised $\partial$-system of the bridging ligand.

The magnetic behaviour of the oxomolybdenum complexes follows the same general pattern, as can be seen from table 2. Once again, if there is an even-atom pathway between the two spins, the exchange interaction is antiferromagnetic and if it is odd, the behaviour is ferromagnetic. Furthermore, when a twist is imposed between two halves of the bridge, as can be seen in comparing the complexes containing $\mathrm{OC}_{6} \mathrm{H}_{4} \mathrm{C}_{6} \mathrm{H}_{4} \mathrm{O}$ and $\mathrm{OC}_{6} \mathrm{H}_{3}(\mathrm{Me}) \mathrm{C}_{6} \mathrm{H}_{3}(\mathrm{Me}) \mathrm{O}$, the exchange interaction is substantially diminished.

\section{Exploiting the optical properties of dinuclear molybdenum species}

We commented above on the unexpected evolution of strong near-IR absorption bands on oxidation of the dinuclear oxomolybdenum diphenolato complexes. This behaviour makes some of these complexes potentially effective as electrochromic near-IR dues in the region of the spectrum of interest for fibre-optic data transmission using silica fibres 
which have absorption minima at $\sim 1300$ and $1550 \mathrm{~nm}$. A number of complexes with absorptions near the target regions were identified and are shown in figure $11^{22,26}$.

In order to test the viability of such species as potential electrochromic near-IR switches, it was necessary to ascertain whether the neutral species and the reduced (dianionic) species are optically transparent in the region around 1300 or $1550 \mathrm{~nm}$, and also if there was a significant separation between the first and second oxidation potential. Spectroelectrochemical examination of these species showed that A (figure 11) was suitable for this testing. The electronic spectra of the mono-cationic, neutral and dianionic species are shown in figure 12, and it is clear that both the neutral and dianionic species are transparent in the range $900-2000 \mathrm{~nm}^{15}$. The monocationic species has two strong absorptions, at 752 and $1342 \mathrm{~nm}$ which are due to phenolate $\rightarrow$ Mo ${ }^{\mathrm{VI}}$ LMCT transitions. On further oxidation to the di-cation, the lower energy transition moves to $c a 1200 \mathrm{~nm}$, but this species gradually decomposes over $\sim 30 \mathrm{~min}$. Fortunately, the oxidation potentials for generation of the mono- and di-cation are sufficiently separate $(+0.44$ and $+0.69 \mathrm{~V})$ that it is possible to generate the former without significantly producing the latter. These optical and electrochemical properties indicate that it was possible to construct a near-IR optical switch, operating by rapid and reversible switching between $\mathbf{A}$ and $\mathbf{A}^{+}$.

A two-electrode optically transparent thin-layer electrode (OTTLE) cell was constructed using two ITO-coated glass slides ${ }^{15}$. The absorption of the cell containing A dissolved in acetonitrile was monitored at $1160 \mathrm{~nm}$ while a stepped potential was applied to the electrodes. A growth in absorption was observed as the potential was increased from 0 to $+1 \cdot 0 \mathrm{~V}$, but significant decomposition of the complex occurred at potentials greater than $1.6 \mathrm{~V}$ due to the formation of the unstable di-cation $\mathbf{A}^{2+}$. Repeated stepping of the applied potential between 0 and $1.5 \mathrm{~V}$ showed reversible optical switching; a process which was repeatable over several thousand cycles before degradation set in. Furthermore, by varying the higher potential step during these experiments within the range of $1.0-1.5 \mathrm{~V}$, the maximum absorbance of the material at a given wavelength could be varied. In other words, the extent of attenuation of the incident light beam could be

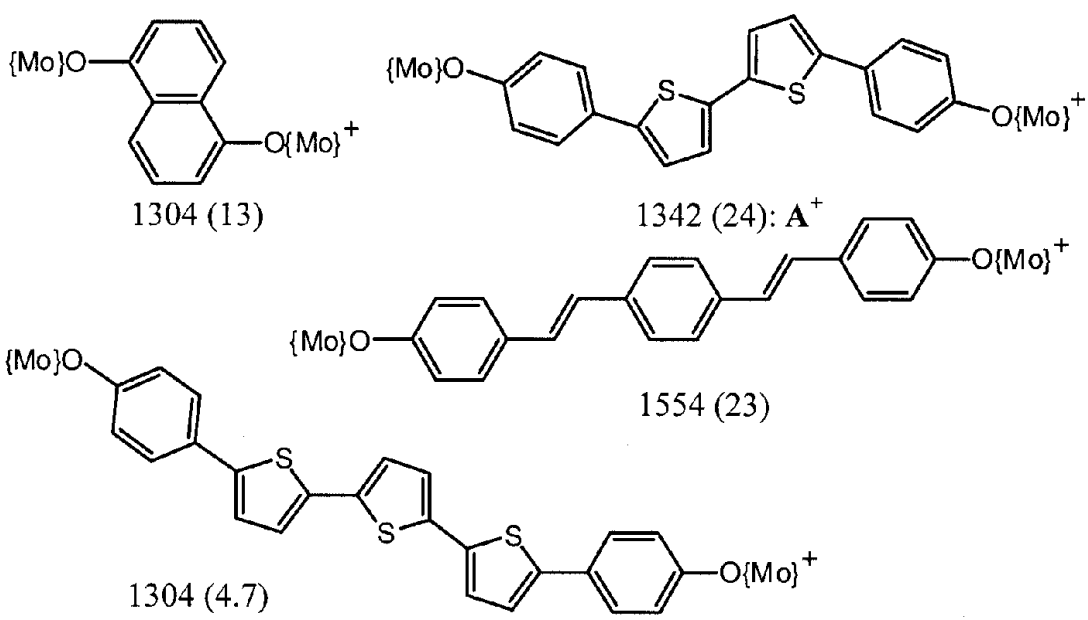

Figure 11. Near-IR absorption maxima for $\left[\{\mathrm{Mo}(\mathrm{O}) \mathrm{Tp} * \mathrm{Cl}\}_{2}(\text { bridge })\right]^{+}$; wavelength in $\mathrm{nm}\left(\varepsilon \times 10^{-3} \mathrm{dm}^{3} \mathrm{M}^{-1} \mathrm{~cm}^{-1}\right) ;\{\mathrm{Mo}\} \equiv\{\mathrm{Mo}(\mathrm{O}) \mathrm{Tp} * \mathrm{Cl}\}$. 


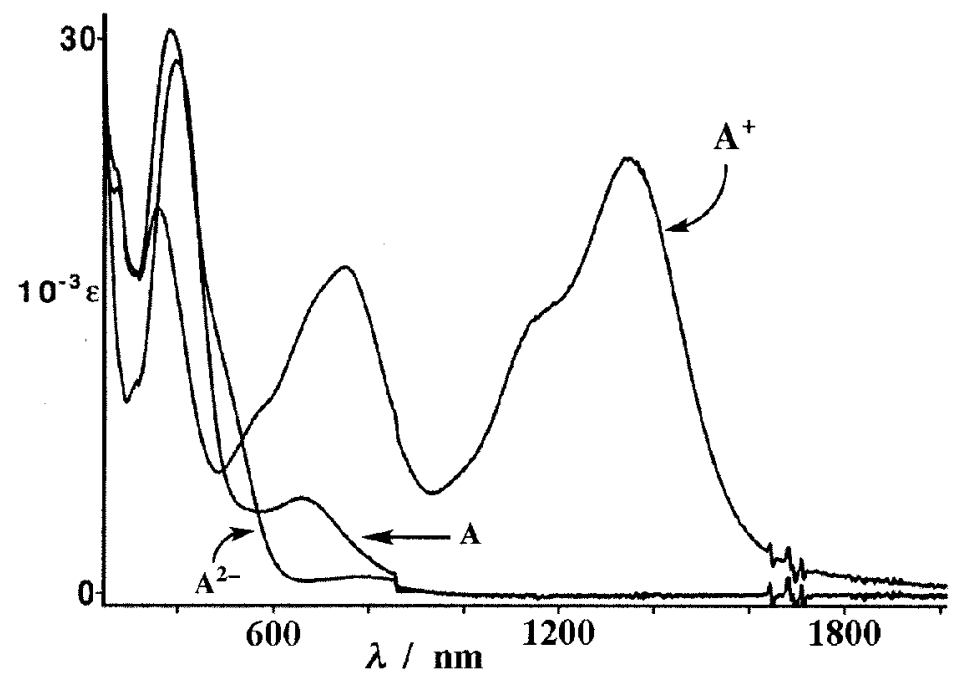

Figure 12. Electronic spectra of $\left[\{\mathrm{Mo}(\mathrm{O}) \mathrm{Tp} * \mathrm{Cl}\}_{2}\left\{\mathrm{OC}_{6} \mathrm{H}_{4}\left(\mathrm{C}_{4} \mathrm{H}_{2} \mathrm{~S}\right)_{2} \mathrm{C}_{6} \mathrm{H}_{4} \mathrm{O}\right\}\right]^{z}$, $\mathrm{A}^{z}, z=0,+1,-2$, in $\mathrm{CH}_{2} \mathrm{Cl}_{2}$ at $-30^{\circ} \mathrm{C}$.

controlled by adjusting the potential. This meant that the material had potential as a variable optical attenuator (VOA) device (in plain English: a dimmer switch!), and subsequent tests showed that the degree of optical power output attenuation was comparable to the best that was currently available from alternative technologies ${ }^{27}$.

We had earlier noticed and have commented above that on reduction of the dinuclear nitrosyl dipyridyl complexes, strong near-IR charge transfer absorptions were generated ${ }^{17}$. Although this behaviour has not been investigated in detail yet, spectroelectrochemical studies of mononuclear $[\mathrm{Mo}(\mathrm{NO}) \mathrm{Tp} * \mathrm{Cl}(\mathrm{pyR})](\mathrm{pyR}=3-$ or 4substituted pyridine) showed that some reduced (monoanionic) species also exhibited significant near-IR MLCT absorptions when $\mathrm{R}=3-\mathrm{CN}$, 3-COMe and $3-\mathrm{COPh}^{19}$. It therefore appears that some of these nitrosyl compounds also have potential as electrochromic dyes for use in electro-optic switching in the near-IR.

\section{Conclusion}

The work described in this report represents perhaps the single most coherent and extensive study of the effect of bridging ligands in metal complexes on the transmission of electronic and magnetic interactions. These interactions are exceptionally strong in the dinuclear nitrosyl and oxo molybdenum complexes mentioned above because of the near ideal matching in both symmetry and energy of the relevant metal orbitals with those of the bridging ligands. Furthermore, spectro-electrochemical studies of the first and second oxidation of $\left[\left\{\mathrm{Mo}(\mathrm{O}) \mathrm{Tp}{ }^{*} \mathrm{Cl}\right\}_{2} \quad(\mu\right.$-diphenolate $\left.)\right]$ revealed that the first charge transfer process is metal-based (giving $\left\{\mathrm{Mo}^{\mathrm{V}}\left(\mu\right.\right.$-diolato) $\left.\mathrm{Mo}^{\mathrm{VI}}\right\}$ species), the second process being either metal-based ( $\left\{\mathrm{Mo}^{\mathrm{VI}}(\mu\right.$-diolato $\left.\left.) \mathrm{Mo}^{\mathrm{VI}}\right\}\right)$ or, because of internal charge redistribution, ligand-based, giving quinonoidal species $\left(\left\{\mathrm{Mo}^{\mathrm{V}}(\mu\right.\right.$-quinone $\left.\left.) \mathrm{Mo}^{\mathrm{V}}\right\}\right)$; the first example of 'non-innocent' behaviour in complexes containing bridging diphenolato ligands. The oxomolybdenum $(\mathrm{V})$ complexes $\left[\left\{\mathrm{Mo}(\mathrm{O}) \mathrm{Tp} \mathrm{C}^{*} \mathrm{Cl}\right\}_{2}(\mu\right.$-diphenolate $\left.)\right]$ exhibited strong 
switchable electrochromism in the near-IR region on oxidation, shown by the appearance of large MLCT bands whose position $\left(\lambda_{\max }=1200-1550 \mathrm{~nm}\right)$ depends on the phenolato link. This led to the development of an electrochromic molybdenum complex whose strong near-IR absorption could be reversibly switched between unoxidised and oxidised forms of the complex, the attenuation of incident light being dependent on the applied voltage. This voltage-dependent attenuation of an incident light beam forms a functional basis for a variable optical attenuator device.

\section{Acknowledgements}

We are grateful to the EPSRC (through postgraduate and postdoctoral support) and the European Commission (through Human Capital \& Mobility and TMR Network grants) for providing the essential underpinning funding of the work described above. Without the skill, perseverance and dedication of our coworkers, whose names appear in the references below, most of the results could not have been obtained. We are extremely grateful to them, and also to Dr C J Jones (University of Birmingham) who played a major role in much of the early work, to Dr John Maher (University of Bristol) for the EPR measurements, to Professor Dante Gatteschi (University of Florence) and his colleagues for magnetic susceptibility measurements, and to Professor Werner Blau (Trinity College, Dublin) who first drew our attention to the significance of electrochromism in the near-IR region.

\section{References}

1. McCleverty J A 1968 Progr. Inorg. Chem. 1049

2. Jørgensen C K 1966 Coord. Chem. Rev. 1164

3. Richter-Addo G B and Legzdins P 1992 Metal nitrosyls (Oxford: Oxford University Press)

4. Hauser C, Glaser T, Bill E, Weyhermüller T and Wieghardt K 2000 J. Am. Chem. Soc. 122 4352

5. Eisenberg R and Gray H B 1964 Inorg. Chem. 6 1844; Schrauzer G N and Mayweg V P 1966 J. Am. Chem. Soc. 88 3235; Welch J H, Bereman R D and Singh P 1988 Inorg. Chem. 27 2862; Chung G W, Bereman R D and Singh P 1994 J. Coord. Chem. 33 331; Kondo M, Minakoshi S, Iwata K, Shimizu T, Matsuzaka H, Kamigata N and Kitagawa S 1996 Chem. Lett. 489

6. (a) Schrauzer G N and Mayweg V P 1965 J. Am. Chem. Soc. 87 3585; (b) McCleverty J A and Ratcliff B 1970 J. Chem Soc. A 1631; (c) Sellmann D, Emig S and Heinemann F 1997 Angew. Chem., Int. Edn. 36 1734; (d) Wieghardt K (personal communication)

7. König E and Herzog S 1970 J. Inorg. Nucl. Chem. 32 585; Hanazaki I and Nagakura S 1972 Bull. Chem. Soc. Jpn. 11 2003; Nakamoto K, Saito Y, Takamoto J and Hutchinson B 1972 Inorg. Chem. 44 2312; Hughes and Macero 1976 Inorg. Chem. 152040

8. Siedle A R 1987 in Comprehensive coordination chemistry (eds) G Wilkinson, R D Gillard and J A McCleverty (Oxford: Pergamon)

9. Buchanan R M, Downs H H, Shorthill W B, Pierpont C G, Kessel S Land Hendrickson DN 1978 J. Am. Chem. Soc. 1007894

10. Lange C W and Pierpont C G 1997 Inorg. Chim. Acta 263219

11. Takvoryan N, Faramery K, Katovis V, Lovecchioi F V, Gore E S, Anderson L B and Busch D H 1986 J. Am. Chem. Soc. 96731

12. McCleverty J A and Ward M D 1998 Acc. Chem. Res. 12 842; McCleverty J A, Ward M D and Jones C J 2001 Comments Inorg. Chem. 22 293; Ward M D and McCleverty J A 2001 J. Chem. Soc., Dalton Trans. 275

13. Psillakis E, Shonfield P K A, Jouaitti A-A, Maher J P, McCleverty J A and Ward M D 2000 J. Chem. Soc., Dalton Trans. 241 
14. Coe B J, Foulon J-D, Hamor T A, Jones C J, McCleverty J A, Bloor D, Cross, G H and Axon T L 1994 J. Chem. Soc., Dalton Trans. 3427; Coe B J, Hamor T A, Jones C J, McCleverty J A, Bloor D, Cross G H and Axon T L 1995 J. Chem. Soc., Dalton Trans. 673; Malaun M, Kowallick R, McDonagh A M, Marcaccio M, Paul R L, Asselberghs I, Clays K, Persoons A, Bildstein B, Fiorini C, Nunzi J-M, Ward M D and McCleverty J A 2001 J. Chem. Soc., Dalton Trans. 3025

15. McDonagh A M, Bayly S R, Riley D J, Ward M D, McCleverty J A, Clowin M A, Morgan C N, Varrazza R, Penty R V and White I H 2000 Chem. Mater. 122523

16. Enemark J H and Feltham R D 1974 Coord. Chem. Rev. 13339

17. McWhinnie S L W, Thomas J A, Hamor T A, Jones C J, McCleverty J A, Collison D, Mabbs F E, Harding C J, Yellowless L J and Hutchings M G 1966 Inorg. Chem. 35 760; Maher J P, McCleverty J A, Navas Badiola J A and Ward M D 1993 J. Chem. Soc., Dalton Trans. 681

18. Thomas J A, Hutchings M G, Jones C J and McCleverty J A 1996 Inorg. Chem. 35289

19. Kowallick R, Jones A N, Reeves Z R, Jeffery J C, McCleverty J A and Ward M D 1999 New J. Chem. 23915

20. Ung V A, Bardwell D A, Jeffery J C, Maher J P, McCleverty J A, Ward M D and Williamson A 1996 Inorg. Chem. 355290

21. Harden N C, Humphrey E R, Jeffery J C, Lee S-M, Marcaccio M, McCleverty J A, Rees L H and Ward M D 1999 J. Chem. Soc., Dalton Trans. 2417

22. Bayly S R, Humphrey E R, de Chair H, Paredes C G, Bell Z R, Jeffery J C, McCleverty J A, Ward M D, Totti F, Gatteschi D, Courric S, Steele B R and Screttas C G 2001 J.Chem. Soc., Dalton Trans. 1401

23. Reitz D C and Weissman S I 1960 J. Chem. Phys. 33 700; Brière R, Dupeyre R-M, Lemaire H, Morat C, Raassat A and Rey P 1965 Bull. Soc. Chim. Fr. 344828

24. Shonfield P K A, Behrendt A, Jeffery J C, Maher J P, McCleverty J A, Psillakis E, Ward MD and Western C 1999 J. Chem. Soc., Dalton Trans. 4341

25. Longuet-Higgins J C 1950 J. Chem. Phys. 18265

26. Bayly S, McCleverty J A, Ward, M D, Gatteschi D and Totti F 2000 Inorg. Chem. 391288

27. Barber B, Giles C R, Askyuk V, Ruel R, Stulzl L and Bishop D 1998 IEEE Photonics Technol. Lett. 10 1262; Kawai T, Koga M, Okuno M and Kotoh T 1998 Electron Lett. 34 264; Jin Y-S, Lee S-S and Son Y-S 1999 Electron Lett. 35916 